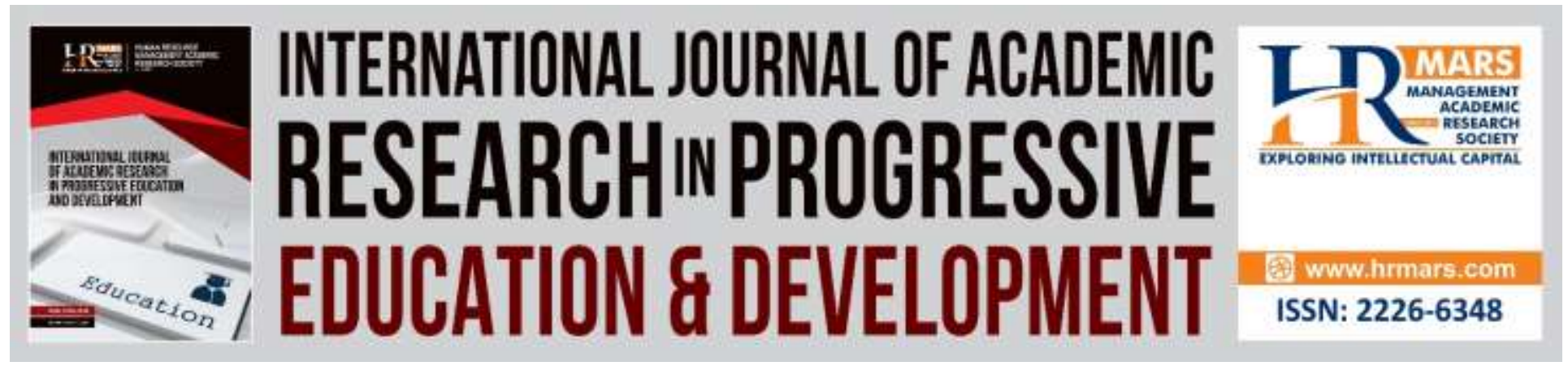

\title{
Students Perception on the Offer of Ethnic Relations Subject in Improving Patriotism Understanding
}

Siti Norayu Mohd Basir, Mohammad Zaini Abu Bakar, Fauziah Ismail, Junainor Hassan

To Link this Article: http://dx.doi.org/10.6007/IJARPED/v9-i2/7294

DOI:10.6007/IJARPED/v9-i2/7294

Received: 15 March 2020, Revised: 17 April 2020, Accepted: 18 May 2020

Published Online: 12 June 2020

In-Text Citation: (Basir et al., 2020)

To Cite this Article: Basir, S. N. M., Bakar, M. Z. A., Ismail, F., \& Hassan, J. (2020). Students Perception on the Offer of Ethnic Relations Subject in Improving Patriotism Understanding. International Journal of Academic Research in Progressive Education and Development, 9(2), 205-216.

Copyright: (C) 2020 The Author(s)

Published by Human Resource Management Academic Research Society (www.hrmars.com)

This article is published under the Creative Commons Attribution (CC BY 4.0) license. Anyone may reproduce, distribute, translate and create derivative works of this article (for both commercial and non-commercial purposes), subject to full attribution to the original publication and authors. The full terms of this license may be seen at: http://creativecommons.org/licences/by/4.0/legalcode

Vol. 9(2) 2020, Pg. 205 - 216

http://hrmars.com/index.php/pages/detail/IJARPED

JOURNAL HOMEPAGE

Full Terms \& Conditions of access and use can be found at http://hrmars.com/index.php/pages/detail/publication-ethics 


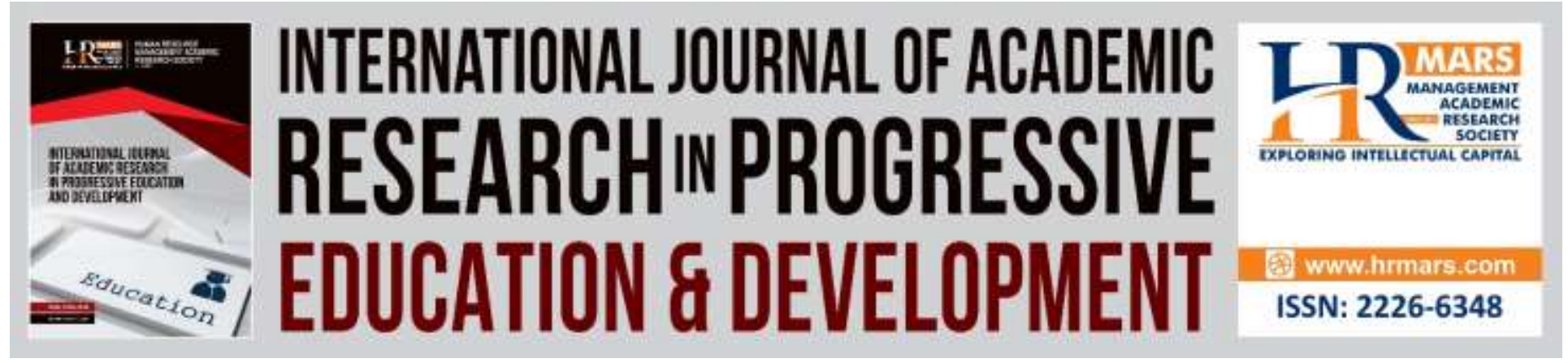

\title{
Students Perception on the Offer of Ethnic Relations Subject in Improving Patriotism Understanding
}

\author{
Siti Norayu Mohd Basir ${ }^{1}$, Mohammad Zaini Abu Bakar², Fauziah \\ Ismail $^{3}$, Junainor Hassan ${ }^{4}$ \\ ${ }^{1,2}$ School of Social Sciences, Universiti Sains Malaysia, 11800 Gelugor, Penang Malaysia, 3,4 \\ School of Human Development and TechnoCommunication, Universiti Malaysia Perlis, 02400, \\ Jejawi Perlis
}

\begin{abstract}
The spirit of patriotism is a necessity in ensuring that the people always support and defend the sovereignty and national security of disruptions and disorders that come from within and beyond. The development of patriotism is very important in producing a group of people who are willing to sacrifice for the country and its people. Although the concept of patriotism is a concept of love of the nation passed from one generation to another, it requires a powerful medium in ensuring that the love of love in this country is always blooming and strong in today's society. Education is one way emphasized in strengthening the understanding and patriotism in Malaysia. Accordingly, a study was conducted in public university especially in Universiti Malaysia Perlis (UniMAP) to see the student's perception on Ethnic Relations Subjects as a medium to enhance the understanding of patriotism. The objective of this study is to examine the differences of students' perception towards the Ethnic Relations subject according to ethnicity, ii) gender and iii) groups that have taken Ethnic Relations subject and groups who have not taken Ethnic Relations subject. The survey method was used and analyzed using Cronbach's Alpha reliability test, and independent-sample t-test.
\end{abstract}

Keywords: Patriotism, General Subject of Ethnic Relations, Perception, Review Study.

\section{Introduction}

The spirit of patriotism is an important and relevant in ensuring the sovereignty, development of the nation can be achieved and maintained to provide Malaysians with a strong identity towards their beloved country. This identity is very important in shaping a society that is willing to sacrifice, a sense of pride, always prioritizing the interests of the community rather than themselves. This spirit of patriotism will shape the heart and soul of the patriotic and responsible young generation in the nation and country. Taking examples of developed countries like the 
Vol. 9, No. 2, 2020, E-ISSN: 2226-6348 @ 2020 HRMARS

United States, Japan, Korea, China and Germany, education is used as one of the mediums in promoting patriotism among the general public and students in particular (Ariely, 2017). Malaysia is also exempt from using the medium of education to foster patriotism values among peoples.

\section{Research Problems}

Various efforts have been undertaken in educating the public to be literate to the values of patriotism. For example, higher education, General Subject points that incorporate several subjects such as Ethnic Relations, Malaysian Studies, and Islamic Civilization and Asian Civilization are introduced as a continuation of historical subjects at primary and 's secondary levels. A thorough study by Ujang, Md., Arifin and Aiyub (2014) used logistic regression analysis method to 500 samples taken from 8 states by North, East, Central, South and Sabah and Sarawak zones shows the level of youth awareness on patriotism are low and worrying. This finding supported by the low patriotism score shown in the Malaysia Youth Index 2015 at the Ministry of Youth and Sports Malaysia. This can be seen in the Malaysia Youth Index (IBM) in 2015 indicating the percentage of identity domains focusing on competitiveness, volunteerism, patriotism, unity, and integrity at a moderate level of $69.1 \%$. Nevertheless, subjects of patriotism under IBM's identity domain showed a decline in IBM's report in 2006 (68.2\%), 2011 (64\%) and 2015 (60.1\%).

While the study conducted by Ahmad, Ling and Abdullah, (2012) found that the subjects taught in secondary schools were still less effective in strengthening the spirit of patriotism among students. The lack of historical subject impact in enhancing the spirit of patriotism among students is due to less effective teaching and learning processes. Education achievement as a medium and strategy of strengthening patriotism is influenced by teaching and learning methods, education policies, resources and expertise (Samsu \& Mohd, 2011, Ahmad, Ling \& Abdullah, 2012; Encep, 2017).

Australia, Germany, and Canada declare a failure to teach the subject of history among their students is caused by repeated subjects. This repeat subject causes students less interested and finds the teaching and learning of this historical subject boring. Besides, the failure of this historical subject is also due to the focus given on the formation of curricula and pedagogy alone without focusing on the development of teaching resources (Samsudin \& Saharudin, 2012). The process of lethargy is due to the capacity of teachers who are less interested, lacking expertise and less emphasizing the concept of patriotism than others that are more easily understood. Teachers should be trained professionally in ensuring the goals and objectives of teaching reach the students. This is because there are teachers who are not historical flows but are forced to teach history. The development of teaching aids should also be given due attention to the same teaching aids cause unattractive and bordem (Samsusin \& Saharudin, 2012).

It is important to be aware about the responsibility to ensuring the country's sovereignty is maintained especially among youths. The difference between the ages and the openness of social media today has led young youth to be inactive and ineffective in understanding and appreciating the spirit of patriotism. In the 21st century, wars are seen as not the only major threats to the sovereignty of a country. This threat is no longer subject to traditional threats such as conflicts that use armed violence and warfare. The threats to national security are widespread and growing, involving threats, which can undermine a non-traditional 
Vol. 9, No. 2, 2020, E-ISSN: $2226-6348$ @ 2020 HRMARS

country such as terrorist threats, drugs, economics, disease and border disputes (Keling, Mohamed \& Suhib, 2016). Thus, national resilience can be maintained with the spirit of patriotism whose value can produce a responsible society, have a high identity, willingness to sacrifice, self-discipline, strong and productive.

\section{Literature Review}

The concept of patriotism is not a new thing in which it exists in line with the existence of human civilization who lives in a small community of big communities who are aimed at maintaining the identity of his people (Salleh, 1995) and synonymous with how a society defends his homeland and culture. Sultanate of Melaka illustrates the beginning of the spirit of patriotism and has evolved around the 17th century until this day (Bakar, 1996). Kleinig (2015) and Gill, Ramli and Talib (2016) argues that a country is desperately need his people to have patriotism values such as a spirit of national love, a spirit of volunteerism, discipline and willingness to sacrifice support the prosperity and sovereignty of a country Youths are generally the heirs who will determine the direction of Malaysia in the future. Today's youth should have a strong identity in the pursuit of a vibrant global stream. Understanding the struggle in the past before independent day should be applied to the general youth and students especially as a form of awareness about the importance of preserving sovereignty, prosperity, and unity that Malaysia enjoys today.

One of the method to emphasis and develop patriotism values among peoples is using education. Historical education is acknowledged to have an impact on building and creating value, feeling and a bond between student and country and is a way to maintain national identity (Sneider, 2013; Zembylas, 2014; Anzai, 2015). The efforts to shape a Malaysian society with the spirit and values of patriotism have been placed in the National Education Policy. The National Education Policy emphasizes the importance of applying the patriotism and national values. It is reinforced by drawing up the ultimate goal of the National Education Policy is to create a loyal and united Malaysian nation. National education policy are an effort in producing knowledgeable, responsible and contributing Malaysians to the development and progress of the nation holistically (National Education Policy, 1979).

Subsequently, the government's initiative in preparing its society was literate history and enthusiastic patriotism by introducing the History Subject. Integrated Secondary School Integrated Curriculum or Kurikulum Brersepadu Sekolah Menengah (KBSM) was introduced to make historical subjects a core subject in line with the National Education Philosophy focusing on physical, spiritual, intellectual and emotional development, historical subjects. Since 2013, History Subjects become compulsory pass subject for all the students who take Malaysian Certificate of Education or Sijil Pelajaran Malaysia (SPM). This effort was made to highlight the seriousness of the government in ensuring that youth are aware about the history and patriotism importance. Taking steps to bend bamboo from its bamboo shoots, Malaysia's efforts continue to take steps to introduce primary school-level history. At the primary level, historical education has been introduced to second-level students, starting in 2014. The aims of this subjects is to provide a core understanding and foster awareness towards Malaysia's history. Among the themes in the curriculum History of primary school is the Theme of Getting to Know Our Country, Citizenship and Country Love. 
Vol. 9, No. 2, 2020, E-ISSN: 2226-6348@ 2020 HRMARS

In fostering the patriotism values in Public and Private Institutes of Higher Learning, the General Subjects have been introduced to all public universities students who were formerly known as Compulsory Subjects (CS) beginning 2013. This continuation is an advanced strategy that shows the Ministry of Higher Education is concerned and supports the government's efforts to produce highly skilled human capital with high teak. The purpose of the CS was to introduce:

i. Coordination of compulsory subjects to general subjects in tertiary education

ii. Nation Construction

iii. Mastery and expansion of soft skills

iv. Strengthening and expanding knowledge about Malaysia

v. Applying soft skills

\section{Research Objectives}

Generally, this study was conducted to examine UniMAP's student perceptions on the offer of GS Ethnic Relations in increasing understanding of patriotism within themselves. In particular, the objectives of this study are:

1. To study student perceptions on the offer of Ethnic Relations subject conducting in UniMAP by ethnics

2. To study student perceptions on the offer of Ethnic Relations subject at UniMAP by gender

3. Looking at whether there is a difference in perception between a group of students who have taken and a group of students who have not taken the Ethnic Relations Subject in UniMAP

\section{Conceptual Framework}

One of the goals of History education in primary and secondary schools and the offering of General Subjects at Higher Education is to foster patriotism among students. This study looks specifically to the Ethnic Relations Subject as comprehensive and gives a deeper understanding of the ethnic diversity scenario in Malaysia. Among the themes breaks in the Second Edition Ethnic Relations Module issued by the Institute of Ethnic Studies are:

i. Malaysia: Integrity in Diversity

ii. Portrait of Ethnic Relations

iii. Overflows of Prosperity Cross-Ethnic

iv. Federal Constitution: Pillar of Ethnic Relations

v. Political Convergence In Ethnic Context In Malaysia

vi. Religious diversity: Finding the Point of Meeting

vii. From Segregation to Integration

viii. Empowerment of Education Towards Social Integration

ix. Daily Experience: Establishing Integrity And Declining Harmony 
Figure 1: Conceptual framework

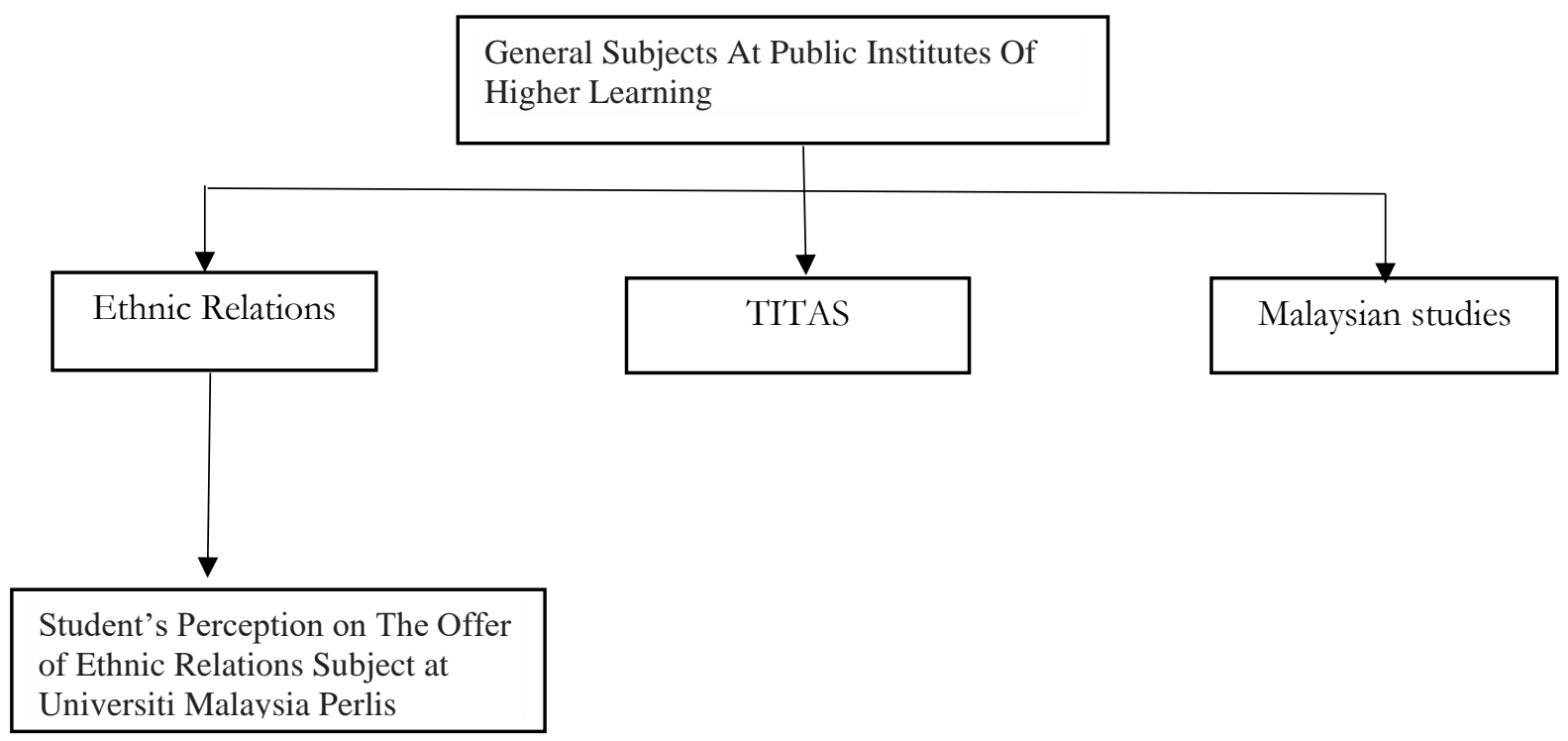

\section{Research Methodology}

The method used in conducting this study was a survey method using questionnaire and was distributed to respondents consisting of UniMAP students. A total of 20 questionnaire papers were distributed for the pilot study. Reliability test is used to see the consistency of questionnaire items. While the actual study uses 200 respondents. The quantitative method of inferential statistical analysis, t-test, is used to identify whether there is a difference in the expected factors can influence the perception of the Ethnic Relations Subject at UniMAP.

The population of this research consists of students of Universiti Malaysia Perlis. In determining sampling selection, the researcher uses a purposive sampling method where researchers have determined the characteristics of the respondents to be involved. Purposive sampling helps in investigating a smaller subset of large populations in which to study all populations involved is impossible (Babbie, 1990). The respondent's criteria consist of two groups:

i. Students who are attending the Ethnic Relations class at UniMAP;

ii. Students who have not attended the Ethnic Relations class at UniMAP

Two groups of respondents were selected to see whether there were differences in the perceptions of the two different groups which had taken and had not taken the GS'S of Ethnic Relations at Universiti Malaysia Perlis. Krejnic and Morgan (1970) suggest that 384 people are enough for every 100,000 population and beyond. A sample of 200 people is sufficient for the student population in UniMAP. However, the researchers did not attempt to generalize the perception of students from two groups who had and had not occupied the Ethnic Relations subject. Therefore, the sample selection is considered to have sufficient information in answer to the research questions. 
INTERNATIONAL JOURNAL OF ACADEMIC RESEARCH IN PROGRESSIVE EDUCATION AND

DEVELOPMENT

Vol. 9, No. 2, 2020, E-ISSN: 2226-6348 @ 2020 HRMARS

Table 1: Student demographics by percentage

\begin{tabular}{llllll}
\hline Gender & $\begin{array}{l}\text { Boys } \\
58(29 \%)\end{array}$ & $\begin{array}{l}\text { Girls } \\
172(71 \%)\end{array}$ & & \\
& & & & \\
& Sciences & Management & Engineering & & \\
& $18(9 \%)$ & $60(30 \%)$ & $122(61 \%)$ & & \\
& & & & Bumiputera & Other \\
Ethnic & Malays & Chinese & Indian & $4(2 \%)$ & $8(4 \%)$ \\
& $89(44.5 \%)$ & $69(34.5 \%)$ & $(15 \%)$ & & \\
\hline
\end{tabular}

Based on the above demographic tables, the number of female students, $172(71 \%)$, is more than male students (58\%). The core breakdown of the study was dominated by 122 students from engineering core (61\%), management core of 60 people (30\%) and core science of 18 (9\%). Meanwhile, for Malay ethnic groups, 89 students (44.5\%), Chinese students 69 (34.5\%), Indian students (15\%), Bumiputera students $4(2 \%)$ and 8 others (4\%).

\section{Reliability Testing on Pilot Research}

The purpose of the pilot study, a total of 20 students were taken as survey respondents. Questionnaires were given to 10 students from groups who had never attended GS's Ethnic Relations and 10 other students who had attended the GS's Ethnic Relations. While the consistency and stability of questionnaire results were tested using item analysis using Cronbach Alpha consistency proposed by Chua (2006) and Darussalam and Hussein (2016), the value of alpha determines the reliability of an item higher the value of alpha, the better the value of the next data will make the study better and more robust.

This method helps researchers determine which items should be retained or eliminated for good questionnaires. The overall value of the items tested is as follows:

Timetable 2: Cronbach's Alpha value on pilot research Reliability Statistics

\begin{tabular}{ll}
\hline $\begin{array}{l}\text { Cronbach's } \\
\text { Alpha }\end{array}$ & N of Items \\
\hline .949 & 8 \\
\hline
\end{tabular}

Based on the table above, the overall value of the Cronbach Alpha coefficient for all items measured is $a=.949$. This shows the degree of trust of the items found in the questionnaire is consistent. 
INTERNATIONAL JOURNAL OF ACADEMIC RESEARCH IN PROGRESSIVE EDUCATION AND

DEVELOPMENT

Vol. 9, No. 2, 2020, E-ISSN: 2226-6348 @ 2020 HRMARS

Table 3: Cronbach's Alpha Value per item

Item

Corrected item Cronbach Alpha If Item total Deleted

correlation

1. Introduction of Ethnic Relations subject

.874

.938

can build student identity

Through the offer of Ethnic Relations

.749

.947

subject, it can foster national unity and

integration.

3. The offer of Ethnic Relations subject can

.749

.943

shape the student's positive character.

4. Values of patriotism within Ethnic

.860

.939

Relations subject are very easy to

understand and appreciate.

5. The Module of Ethnic Affairs is in line with

.841

.940

today's community issues.

6. Offers Ethnic Relations subject enhances

.945

.934

the spirit of student patriotism.

7. Ethnic Relations subject gives a deep

.676

.950

understanding of the country.

8. The offer of Ethnic Relations subject helps

.780

.945 students understand and respect the differences in cultures, languages, and religions of multi-ethnic communities in Malaysia.

In general, each item in the instrument used has a high alpha value of more than 0.60 . This is supported by the statement of Konting (1993) where alpha 0.60 is sufficient and acceptable and Nunnally (1978) alpha value greater than 0.70 is acceptable. This indicates that the reliability of this item is acceptable as it exceeds 0.60 and all items can be maintained.

\section{Research Objectives One}

Studying the level of perceptions of different ethnic groups towards the Ethnic Relations subject in enhancing the understanding of patriotism in UniMAP.

Table 5: Students perception on the ethnic relations subject offering by ethnicity

\begin{tabular}{llll}
\hline Ethnic & Mean & $\mathrm{N}$ & Standard deviation \\
\hline Malays & 3.6657 & 89 & .40844 \\
Chinese & 3.4583 & 69 & .49708 \\
Indian & 3.7375 & 30 & .64773 \\
Bumiputera & 2.8125 & 4 & .07217 \\
Others & 3.4375 & 8 & .46771 \\
\hline
\end{tabular}


Vol. 9, No. 2, 2020, E-ISSN: 2226-6348@ 2020 HRMARS

The findings show that among the five ethnic groups involved in the study, Indian ethnic respondents perception on Ethnic Relations subject would increase the understanding of patriotism is higher than other ethnic groups (3.7375), followed by Malays (3.6657) Chinese (3.4583), students from other ethnic groups (3.4375) and Bumiputera (2.8125).

\section{Research Objectives Two}

Studying student perceptions of different gender towards the offer of Ethnic Relations Subject in improving patriotism in UniMAP.

Table 6: Perceptions Of Ethnic Relations Subject Perceptions By Gender

\begin{tabular}{llllllll}
\hline Demography & Factor & $\mathrm{N}$ & Min & $\mathrm{sp}$ & $\mathrm{dk}$ & $\mathrm{t}$ & sig \\
\hline Gender & Boys & 58 & 3.482 & .54130 & 198 & .951 & .343 \\
& Girls & 142 & 3.618 & .48143 & & & \\
\hline
\end{tabular}

Based on table 6, it is found that the female students 'mean is 3.618 compared to the male students' mean of 3.482 but the difference in value is small. Sig value .343 ( $p>.05)$ shows that there is no significant difference between male and female students when discussing the perception on the offer of Ethnic Relations subject in enhancing the understanding of patriotism in UniMAP.

\section{Research Objective Three}

Looking at whether there are differences in perceptions between the group of students who have taken and the group of students who have not taken the Ethnic Relations subject in UniMAP

Table 7: Perceptual Differences of Ethnic Subject Perceptions According to Group Who Have Taken and Have Not Taken Subject Ethnic Relations

\begin{tabular}{llllllll}
\hline Demography & Factor & $\mathrm{N}$ & Min & $\mathrm{sp}$ & $\mathrm{dk}$ & $\mathrm{t}$ & $\mathrm{sig}$ \\
\hline Group & Taken & 100 & 3.54 & .49 & 117 & .663 & 0.509 \\
& Not taken & 100 & 3.60 & .50 & & &
\end{tabular}

Based on Table 3, the t-values for the comparison of the group of students who have taken and have not taken Ethnic Relations subject are $t=0.663$ and the significant level $p=0.509$. This significant level is greater than 0.05 ( $p>0.05$ ). There is no significant difference to the offer of Ethnic Relations subject according to the group of students who have taken and have not taken the subject. The mean score of the group of students who took ( $\min =3.54$ ) was smaller than the group of students who never took ( $\min =3.60)$.

\section{Discussions}

From the findings, the perception of the Ethnic Relations subject in improving the understanding of patriotism among students is different according to ethnicity. Indian students recorded the highest mean value compared to Malay and Chinese students. In this group of three 
ethnic majorities, Chinese students record the lowest mean value. Among the factors that cause these differences is that each student has an understanding of the concept of different patriotism and is based on their ethnic interests. Divide and Rules Policies left by the British have once formed a landscape of ethnic identity today. Strong ethnic identity led to an understanding of the concept of patriotism over how to preserve ethnic interests rather than national interest.

This can be seen as an understanding of the concept of Malay student patriotism over defending the special privileges of the Malays as Wataniah, Chinese students fighting for rights such as Chinese language retention, economic mastery, and Chinese school education rights. It is a pride when Indian ethnics record the highest mean of their factor in the effort to adapt to the environment as a means of survival in terms of education, economics and social (Ahmad, Ling \& Abdullah, 2012). A more neutral approach without emphasizing ethical issues is seen as one way to ensure that students are keen on education to promote patriotism as the learned value (Bruces, 2009). They should be given away in discussing matters related to an ethnicity so that the understanding of a non-weighted understanding can be constructed.

Besides, there was no significant difference when discussing the perception of the Ethnic Relations subject in raising the spirit of patriotism among groups of students who have and have not taken the subject of Ethnic Relations subject. Among the factors influencing this finding are these students have been exposed to historical education that applies patriotism values through the Integrated School Curriculum (KBSM, 1989) and converted into the Secondary School Standart Curriculum (KSSM) in 2017. The average student states the teaching and learning the Malaysian Nationality is rather boring and they agree that the more creative approach is demanded in ensuring the teaching and learning it can have the desired impact (Samsu \& Nor, 2014). Education plays a comprehensive role in describing the diversity of communities in Malaysia. It should help develop a common understanding of the concept of patriotism and identity as a Malaysian.

\section{Conclusion}

The discussion on the relationship between the roles of education in producing a student with high-spirited of patriotism will never end. There is a general concern on whether education emphasizes the values of patriotism among students as expected. This concern can be explained by increasing social problems among adolescents. The effectiveness of subject-related subjects and history of patriotism is likewise to the way the teachers and lecturers handle their classes and lectures. Studies show repeated teaching cause this subject is not favoured by students at the same time not getting a response in appreciating every value contained in the subject.

Educating youth about how important maintaining the patriotism in their blood is crucial. It can be our shield in dealing with national security in modern world, social problems among youth, and also as a medium to make sure Malaysia will move forward as a develop country in the future. Without the feeling of belonging to the nation, and love to the country, youth can easily be manipulating by outsider. 
INTERNATIONAL JOURNAL OF ACADEMIC RESEARCH IN PROGRESSIVE EDUCATION AND

DEVELOPMENT

Vol. 9, No. 2, 2020, E-ISSN: 2226-6348 @ 2020 HRMARS

\section{Corresponding Author}

Siti Norayu Mohd Basir, Mrs. Malaysia, norayu@student.usm.my, School of Social Sciences, Universiti Sains Malaysia, 11800 Gelugor, Penang, Malaysia

\section{References}

Ahmad, Ling P. H. H., \& Abdullah, N. A. T. (2012). Pengetahuan nilai patriotisme pelajar berdasarkan pembelajaran subjek sejarah. Malaysian journal of youth studies,13, 95-116.

Ahmad, A. (2010). Pentaksiran Pembelajaran. Kuala Lumpur: Dewan Bahasa dan Pustaka

Anzai, S. (2015). Re-Examining Patriotisme In Japanese Education: Analysis of Japanese Elementary School Moral Readers. Educational Review, 67(4), 436-458

Ariely, G. (2017). Evaluations of Patriotism Across Countries, Groups, And Policy Domains. Journal of Ethnic and Migration Studies, 44(3), 462-481

Babbie, E. (1990). Survey Research Methods. California: Wadsworth Publishing

Bakar, A. L. A. (1996). Konsep Patriotisme dan Nasionalisme. Kuala Lumpur : Penerbit Universiti Malaya.

Bruces, H. (2009). Patriotisme and Citizenship Education. United States: Wiley-Blackwell Publicatio Buku Dasar Pendidikan Kebangsaan. www.moe.gov.my/index.php/my/dasar/dasar-pendidikan-kebangsaan

Chua, Y. P. (2006). Kaedah Dan Statistik Penyelidikan: Kaedah Penyelidikan Buku 1. Selangor: Mcgraw- Hill .

Darussalam, G., \& Hussin, S. (2016). Metodologi Penyelidikan Dalam Pendidikan : Amalan dan Analisi Kajian. Kuala Lumpur: Penerbit Universiti Malaya.

Encep, S. N. (2017). Civic Education Policies: Their Effect on University Students' Spirit of NationalismAnd Patriotism. Citizenship, Social and Economic Education, 44(1),1728.

Gill, S. S., Ramli, M. R., \& Talib, A. T. (2015). Kesedaran Patriotik dalam Kalangan belia Bandar di Semenanjung Malaysia. Jurnal Sosial Ilmu Politik Universitas Hasanudin, 1(1), 111-120.

Keling, M. F., Mohamed, A. S. P., \& Suhib, A. S. (2016). Dasar Pertahanan Negara Malaysia: Adakah ianya Kukuh. Jurnal Indonesia untuk Kajian Pendidikan, 1(1), 101-122

Kementerian Belia dan Sukan. (2015). Indeks Belia Malaysia. Institut Penyelidikan Pembangunan Belia Malaysia (IYRES).

Kleinig, J., Keller, S., \& Primoratz, I. (2015) . The Ethics of Patriotism: A Debate. Singapore: Wiley Blackwell.

Konting, M. J. (2000). Kaedah Penyelidikan Pendidikan. Edisi ke-5. Kuala Lumpur.

Dewan Bahasa dan Pustaka.

Krejcie, V. R., \& Morgan, W. D. (1970). Determining Sample Size For Research Activities, Educational And Psychological Measurement. Duluth: University Of Minnesota

Ku Samsu, K. H., \& Mohd, N. M. H. (2011). Kepentingan Pendidikan Patriotisme Terhadap Wargenagara Malaysia. Journal of Southeast Asian Studies, 16, 23-24 
INTERNATIONAL JOURNAL OF ACADEMIC RESEARCH IN PROGRESSIVE EDUCATION AND

DEVELOPMENT

Vol. 9, No. 2, 2020, E-ISSN: 2226-6348 @ 2020 HRMARS

Muhammad, Z., Jawan, J., \& Ahmad, Z. (2010). Kesan Penawaran Kursus Umum Universiti Ke Atas Pelajar Institusi Pengajian Tinggi Awam dan Swasta. Jurnal Pengajian Umum

Asia Tenggara, 11 , 73-89.

Nunnally, J. C. (1978). Psychometric Theory (2 ${ }^{\text {nd }}$ ed.). New York: McGraw-Hill.

Salleh, A. H. (1995). Patriotisme dan Globalisasi dalam Konteks Pergerakan Bahasa dan Sastera Kebangsaan. Kuala Lumpur: Dewan Bahasa dan Pustaka

Samsudin, M., \& Saharudin, S. (2012). Pendidikan Pengajaran Matapelajaran Sejarah di Sekolah Di Malaysia. Jebat: Malaysian Jurnal of History, Politics \& Strategy,39(2), 116-141

Sneider, D. (2013). Textbooks and Patriotic Education: Wartime Memory Formation in China and Japan, Asia-Pacific Review, 20(1), 35-54

Ujang, A., Md., J. J., \& Arifin, K. (2014). Kesedaran Generasi Muda Terhadap Patriotisme dan Perpaduan Nasional di Malaysia. Jurnal Antarabangsa Alam dan Tamadun Melayu, 2 (2), 31-39.

Zembylas, M. (2014). The Teaching of Patriotism and Human Rights: An Uneasy Entanglement And The Contribution Of Critical Pedagogy. Educational Philosophy and Theory, 46(10), 1143-1150 